\title{
PEMANTAUAN EKOSISTEM LAMUN PULAU PARI DAN PULAU TIKUS
}

\section{MONITORING OF SEAGRASS ECOSYSTEM AT PARI ISLAND AND TIKUS ISLAND}

\author{
Agustin Rustam \\ Pusat Riset Kelautan, Badan Riset dan Sumberdaya Manusia Kelautan dan Perikanan, \\ Kementerian Kelautan dan Perikanan \\ Jl. Pasir Putih I, Ancol Timur-Jakarta Utara \\ Telp:+62 2164711583 , Fax: +62 2164711654. \\ e-mail : agustin.rustam@kkp.go.id
}

Diterima: 14 Juni 2019 ; Perbaikan: 02 Juli 2019 ; Disetujui: 15 Agustus 2019

\begin{abstract}
ABSTRAK
Monitoring atau pemantauan yang dilakukan terhadap ekosistem lamun pada lokasi permanen diperlukan mendapatkan sumber masalah dan solusi untuk pengelolaan ekosistem yang berkelanjutan. Penelitian ini dilakukan tahun 2012 di perairan Gugusan Pulau Pari, Kabupaten Kepulauan Seribu, DKI Jakarta dengan pemasangan lokasi permanen di dua pulau, Pulau Pari dan Pulau Tikus. Tujuan penelitian ini mendapatkan dinamika kondisi eksisting ekosistem lamun melalui pendekatan persentase tutupan lamun. Metode penelitian dilakukan dengan survei lapangan yang berkelanjutan (monitoring), penentuan lokasi permanen berdasarkan hipotesa Pulau Pari terpengaruh aktivitas daratan, Pulau Tikus tidak terpengaruh. Hasil penelitian jenis lamun yang ditemukan di gugusan Pulau Pari ada tujuh jenis. Hasil monitoring terlihat adanya kecenderungan penurunan persentase penutupan lamun dan berkurangnya spesies lamun di Pulau Pari, sedangkan di Pulau Tikus terlihat stabil. Aktivitas pembangunan yang berlangsung di Pulau Tengah berperan cukup besar atas penurunan persentase tutupan lamun di Pulau Pari selama penelitian, juga potensi pencemaran limbah domestik dari masyarakat lokal maupun dari wisatawan. Pemantauan pada lokasi permanen perlu dilanjutkan sehingga permasalahan yang terjadi dengan ekosistem di Gugusan Pulau Pari dapat dicari solusinya. Misalnya terkait dengan tingginya aktivitas wisatawan, perlu pembelajaran tentang ekowisata yang baik bagi wisatawan dan masyarakat lokal, misalnya dalam penanganan limbah. Sehingga diharapkan pemanfatan ekosistem yang berkelanjutan dalam tujuan pembangunan berkelanjutan dapat dilakukan
\end{abstract}

Kata kunci: Lamun, Pulau Tikus, Pulau Pari.

\section{ABSTRACT}

Monitoring carried out on seagrass ecosystems in permanent locations is needed to get sources of problems and solutions for sustainable ecosystem management. This research was conducted in 2012 in the waters of Pari Island Cluster, Seribu Islands Regency, DKI Jakarta by installing permanent locations on two islands, Pari Island and Tikus Island. The purpose of this study was to obtain the dynamics of the existing conditions of seagrass ecosystems through an approach to the percentage of seagrass cover. The research method was carried out by a continuous field survey (monitoring), the determination of a permanent location based on the Pari Island hypothesis was affected by land activities, Tikus Island was not affected. The results of the research on seagrass species found in the Pari Island cluster are seven types. The monitoring results showed a tendency to decrease the percentage of seagrass closure and reduced seagrass species in Pari Island, while in Pulau Tikus it was stable. The development activities that took place at Tengah island have a significant role in reducing the percentage of seagrass cover in Pari Island during the research, as well as the potential for domestic waste pollution from local communities as well as tourists. Monitoring on a permanent location needs to be continued so that the problems that occur with the ecosystem in the Pari Island Cluster can be found a solution. For example, related to the high activity of tourists, it is necessary to learn about ecotourism that is good for tourists and local communities, for example in handling waste. So that it is expected that sustainable utilization of ecosystems in sustainable development goals can be carried out.

Keywords: seagrass, Tikus island, Pari island.

Pemantauan Ekosistem Lamun Pulau Pari Dan Pulau Tikus - Agustin Rustam 


\section{PENDAHULUAN}

Lamun merupakan tanaman sejati Angiospermae, ekosistem lamun mempunyai fungsi sebagai produser, habitat biota (tempat pemijahan, daerah asuhan, daerah mencari makan), sebagai penangkap sedimen, sebagai pendaur zat hara. Menurut Philips \& Menez (1988), ekosistem lamun merupakan salah satu ekosistem bahari yang produktif di perairan dangkal. Ekosistem lamun merupakan ekosistem yang kaya dengan sumber makanan untuk herbivora, omnivora, zoobenthivora dan zooplanktivora, dan piscivores sehingga ekosistem lamun menjadi tempat mencari makan untuk berbagai biota yang hidup di ekosistem mangrove dan terumbu karang, terutama untuk ikan karang di pulau pulau kecil (Nagelkerken et al., 2002; Nagelkerken et al., 2006). Peranan dan fungsi ekosistem lamun yang sangat produktif dan fungsi lainnya maka ekosistem lamun memiliki nilai tertinggi diantara ekosistem lainnya (Costanza et al., 1997).

Eksistensi lamun di laut merupakan hasil dari beberapa adaptasi yang dilakukan termasuk toleransi terhadap salinitas yang tinggi, kemampuan untuk menancapkan akar di substrat sebagai jangkar, dan juga kemampuan untuk tumbuh dan melakukan reproduksi pada saat terbenam. Jumlah jenis tumbuhan lamun mencapai 60 jenis lamun yang terbagi dalam 13 genus dan 5 famili (Short et al., 2001) dengan konsentrasi utama didapatkan di wilayah Indo-Pasifik. Dari jumlah tersebut 16 spesies dari 7 genus diantaranya ditemukan di perairan Asia Tenggara, dimana jumlah spesies terbesar ditemukan di perairan Filipina sebanyak 16 spesies. Di Indonesia ditemukan jumlah jenis lamun yang relatif lebih rendah dibandingkan Filipina, yaitu sebanyak 13 spesies dari 7 genus dengan satu spesies terbaru ditemukan tahun 2007 di perairan Spermonde, Sulawesi Selatan yaitu Halophila sulawesii (Kuo, 2007).

Monitoring atau pemantauan ekosistem lamun dengan protokol standar diperlukan untuk mengetahui perubahan ekosistem sehingga dapat diketahui penyebabnya dan dicari solusinya dalam pengelolaan yang berkelanjutan. Salah satu contoh adalah protocol standar yang disusun oleh SeagrassNet mendapatkan hasil pemantauan satu - dua tahun di Amerika didapat beberapa kasus hasil monitoring yang terjadi, salah satunya adalah penurunan ekosistem lamun akibat pengayaan nutrient (eutrofikasi) (Short et al., 2006a).

Bioindikator adalah biota yang dapat digunakan sebagai petunjuk keberadaan lokasi, kesehatan lingkungan ataupun komposisi komponen biota lainnya. Bioindikator umumnya adalah biota yang keberadaannya cukup stabil dalam lingkungan. Keberadaan lamun dalam suatu perairan dapat dimanfaatkan sebagai suatu indikator bagi kesehatan perairan di pulau Lembeh Sulawesi Utara (Rustam et al., 2015), bioindikator keberadaan logam berat (Rappe, 2010; Li \& Huang, 2012) ataupun kesehatan lingkungan lainnya seperti di estuaria (River Science, 2013). Berbagai literatur sudah umum menyatakan keberadaan ekosistem lamun yang luas mengindikasikan kesehatan perairan yang bagus kebalikan dengan keberadaan makro alga (Marba et al., 2013).

Kepulauan Seribu merupakan bagian dari Provinsi Daerah Khusus Ibukota Jakarta yang berada di depan Teluk Jakarta. Teluk Jakarta merupakan muara dari 13 sungai besar seperti Sungai Ciliwung dan Sungai Citarum yang membawa limbah dari daratan. Keberadaan limbah yang banyak akan mempengaruhi kondisi perairan dan kondisi ekosistem, contohnya ekosistem lamun. Kepulauan Seribu dikenal sebagai daerah tujuan wisata khususnya masyarakat Jakarta dan sekitarnya. Keberadaan ekosistem yang cukup lengkap (ekosistem terumbu karang, ekosistem lamun dan ekosistem mangrove) di Kepulauan Seribu menjadikan daya tarik para wisatawan dan menjadikan beberapa pulau berpenghuni menjadi suatu resort atau homestay yang dikelola masyarakat setempat. Tingginya tingkat aktifitas manusia di pulau-pulau berpenghuni terutama aktivitas wisata bahari dapat juga menganggu keberadaan ekosistem. Penelitian ini bertujuan untuk mendapatkan kondisi eksisting dan dinamika keberadaan lamun dan kondisi lingkungan di lokasi penelitian dan peranan lamun sebagai bioindikator kesehatan lingkungan perairan berdasarkan kriteria baku mutu KepmenLH No 200 Tahun 2004.

\section{BAHAN DAN METODE}

\section{Lokasi Pengambilan Data}

Lokasi penelitian di dua pulau dalam gugusan Pulau Pari yaitu pulau Tikus dan Pulau Pari (Gambar 1). Penentuan lokasi berdasarkan hipotesa tingginya dampak aktivitas manusia terhadap prekosistem lamun Lokasi transek permanen di Pulau Tikus berada di bagian luar gugusan yang berhadapan langsung dengan laut Jawa tidak ada pemukiman, lokasi transek permanen di Pulau Pari berada di dalam gugusan pulau yang merupakan daerah rataan terumbu karang dan dekat dengan pemukiman. 


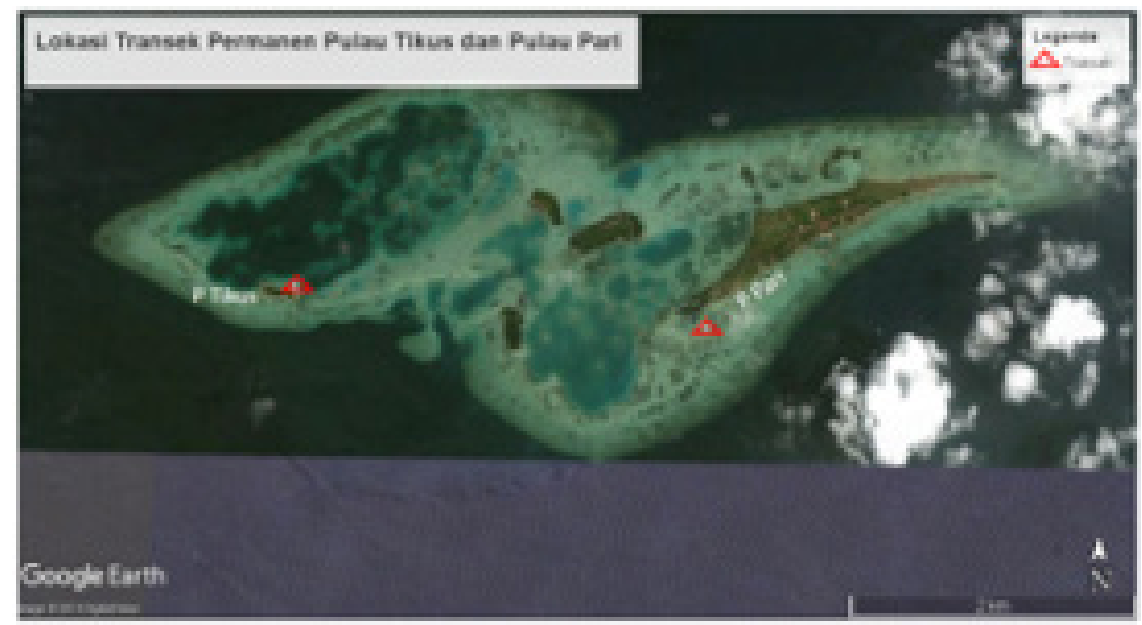

Gambar 1. Lokasi penelitian.

\section{Metode Pengumpulan Data dan Sampel}

Metode penelitian yang dilakukan adalah metode survei yang berulang (monitoring) pada lokasi permanen. Penentuan transek dilakukan dengan hipotesis ekosistem lamun tidak dipengaruhi aktivitas daratan ( $\mathrm{P}$ Tikus), ekosistem lamun dipengaruhi aktivitas daratan (P Pari). Metode pengambilan data lamun yang dilakukan secara transek garis (line transect) modifikasi SeagrassNet (Short et al., 2008). Transek garis ditarik sejajar garis pantai dan kemudian kuadrat berukuran $50 \times 50 \mathrm{~cm}^{2}$ diletakkan secara sistematik dengan jarak antar kuadrat telah ditentukan dalam meteran SeagrassNet (Short et al., 2006a). Jarak antar transek 25 meter (Gambar 2). Pemasangan transek permanen dengan memasang pasak besi sedalam kurang lebih $50 \mathrm{~cm}$ pada tiap ujung dan bagian tengah transek $(0 \mathrm{~m}, 25 \mathrm{~m}$ dan $50 \mathrm{~m})$. Kuadrat yang diletakkan pada transek A pada meter ke: $2 ; 7 ; 8$; $16 ; 18 ; 25 ; 26 ; 22 ; 38 ; 40 ; 44$ dan 46 . Transek B kuadrat diletakkan pada meter ke: $9 ; 10 ; 15 ; 17 ; 22 ; 25 ; 28 ; 31$; 35; 37; 39 dan 45. Transek C kuadrat diletakkan pada meter ke: $5 ; 7 ; 10 ; 18 ; 19 ; 22 ; 26 ; 34 ; 35 ; 38 ; 43$ dan 44.

Parameter yang diambil di setiap stasiun penelitian adalah persentase tutupan tajuk lamun dalam setiap kuadrat $50 \times 50 \mathrm{~cm}^{2}$ diambil dengan metode estimasi visual berdasarkan panduan persentase tutupan lamun standar SeagrassWatch (McKenzie et al., 2003). Persentase tutupan yang diambil adalah persentase tutupan total lamun dan persentase tutupan setiap jenis lamun dalam kuadrat.

\section{Analisis Data}

Analisis deskriptif perubahan persentase tutupan lamun dalam 3 periode di tahun 2012 untuk mengetahui kondisi ekosistem lamun. Selain itu dilakukan analisis kajian penyebab perubahan yang terjadi berdasarkan kajian literatur dan kondisi pada saat penelitian.

\section{HASIL DAN PEMBAHASAN}

Gugusan Pulau Pari merupakan bagian dari

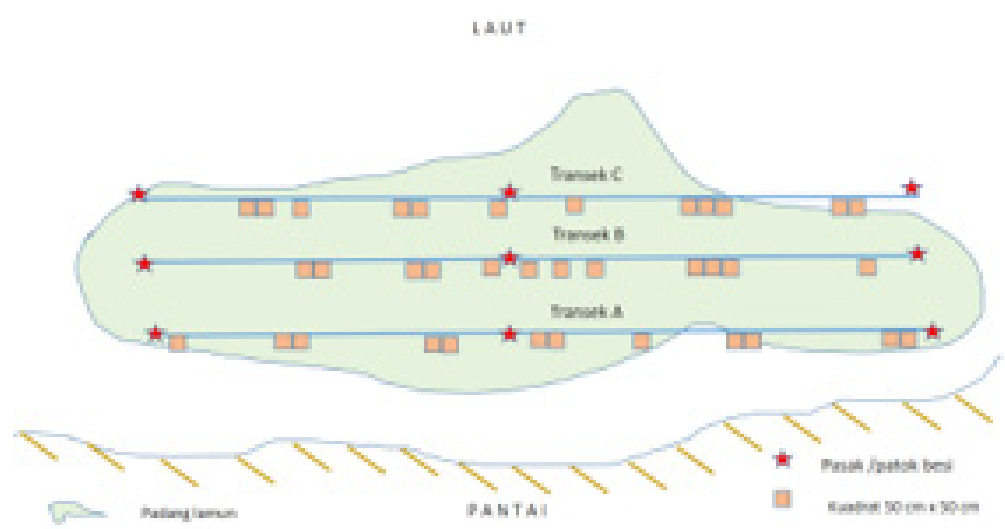

Gambar 2. Lokasi transek permanen yang dilakukan di pulau Tikus dan Pulau Pari. (modifikasi dari SeagrassNet).

Pemantauan Ekosistem Lamun Pulau Pari Dan Pulau Tikus - Agustin Rustam 
Kepulauan Seribu yang berada kurang lebih $45 \mathrm{~km}$ dari Jakarta, terdiri dari Pulau Pari, Pulau Tengah, Pulau Kongsi, Pulau Tikus, Pulau Burung dan Pulau Kudus. Pulau berpenghuni adalah pulau Pari, namun pulau Tengah sejak pembangunan tahun 2011 telah menjadi resort dengan kurang lebih 100 resort/rumah yang mengelilingi pulau. Pulau Kongsi merupakan instalasi riset dari Pusat Riset Perikanan, Kementerian Kelautan dan Perikanan.

Gugusan pulau Pari merupakan rataan terumbu karang dan goba yang menghubungi beberapa pulau kemudian tubir yang cukup dalam mengelilingi gugusan pulau. Susunan substrat permukaan secara garis besar di dasar perairan ini terdiri atas pecahan batu karang mati dan hidup, pasir kasar-pasir halus, dan lumpur (Nurdiansyah, 2007). Kondisi perairan secara visual selama penelitian (tahun 2012) terlihat agak keruh karena adanya pembangunan resort di Pulau Tengah, dengan pantai landai berpasir putih. Terkadang pada waktu tertentu misalnya menuju surut perairan di lokasi penelitian terlihat cukup jernih.

\section{Kondisi Eksisting Ekosistem Lamun di Pulau Tikus dan Pulau Pari}

Ekosistem lamun yang ditemukan di gugusan Pulau Pari selama penelitian sebelum membuat lokasi permanen terdapat tujuh jenis lamun. Lamun yang ditemukan yaitu jenis Enhalus acoroides, Thalassia hemprichii, Syringodium isoetifolium, Cymodocea rotundata, Cymodocea serrulata, Halodule uninervis dan Halophila ovalis.

Pengukuran awal di lokasi permanen pulau Pari pada bulan Mei 2012 ditemukan tiga jenis lamun yaitu Thalassia hemprichii, Enhalus acoroides dan Cymodocea rotundata. Jenis Syringodium isoetifolium, Halodule uninervis, Cymodocea rotundata dan Halophila ovalis ditemukan mendekati tubir. Sedangkan untuk pulau Tikus pada awal pengukuran Mei 2012 sebanyak enam jenis lamun kecuali Halophila ovalis. Tidak ditemukannya Halophila ovalis selama penelitian dapat disebabkan karena pengaruh fisik adanya sedimentasi yang disebabkan pembangunan resort pulau Tengah yang membuat alur pelayaran sendiri untuk membawa material dan peralatan pembangunan. Pembuatan alur ini dengan cara memperdalam alur yang ada sehingga menggali untuk memperdalam alur yang merusak karang dan mengangkat substrat/sedimen dasar perairan yang menyebabkan terjadi sedimentasi cukup tinggi di sekitar lokasi khususnya wilayah di gugusan pulau Pari. Halophila ovalis merupakan lamun yang berukuran kecil sehingga keberadaannya tidak terlihat karena tertutup pasir.

Kondisi awal (Mei 2012) nilai persentase tutupan total lamun di dua lokasi permanen berkisar antara 0-40 \% untuk Pulau Pari dan 0-95\% untuk Pulau Tikus. Plot permanen dari 3 transek untuk masing-masing lokasi (P. Tikus dan P. Pari) adalah 36 plot. Lamun yang ditemukan di Pulau Pari sebanyak $56 \%$ (20 plot) sedangkan di Pulau Tikus lebih tinggi yaitu $86 \%$ (31 plot). Hal ini mengindikasikan ekosistem lamun di Pulau Pari dalam kondisi lebih tertekan dibandingkan di Pulau Tikus karena dekat dengan pemukiman.

\section{Dinamika Jumlah Jenis dan Persentase Total Tutupan Lamun Pulau Tikus dan Pulau Pari}

Kondisi pembangunan resort di Pulau Tengah yang masih berlangsung pada tahun 2012 mempengaruhi dinamika lamun baik jenis maupun persentase tutupan. Dinamika jenis lamun yang ditemukan dalam transek permanen di dua pulau selama tiga kali penelitian terlihat pada bulan Juli 2011 pada kedua pulau jumlah jenis lamun yang ditemukan menurun kemudian meningkat di bulan November 2012 untuk pulau Tikus dan stabil untuk pulau Pari (Gambar 3).

Persentase total tutupan lamun selama penelitian berkisar antara 0 - $40 \%$ di bulan Juli 2012 dengan transek B dari 12 plot tidak ditemukan lamun, bulan November 2012 berkisar antara $0-50 \%$. Nilai persentase total tutupan lamun terlihat adanya perubahan baik dalam setiap transek maupun plot. Perubahan persentase total tutupan lamun di Pulau Pari terlihat adanya indikasi penurunan persentase total tutupan lamun terutama di transek C (Gambar 4).

Transek A ditemukan tiga jenis lamun dalam pengamatan selanjutnya hanya ditemukan dua jenis lamun. Hal ini dapat disebabkan adanya kecenderungan peningkatan nutrient dari daratan dan proses fisik (sedimentasi) akibat penggalian substrat dasar sehingga partikel pasir menutupi keberadaan lamun selain kondisi pasang surut perairan (Gambar 5). Selain itu aktivitas wisatawan yang tinggi dengan aktivitas dilakukan terutama di ekosistem lamun juga dapat menjadi salah satu faktor penyebab degradasi lamun.

Kondisi yang berbeda dengan pemantauan di Pulau Tikus. Nilai kisaran persentase total tutupan lamun di bulan Juli dan November 2012 sebesar 0$100 \%$. Perubahan yang terlihat di pulau Tikus berbeda dengan Pulau Pari terlihat pengaruh proses fisik 


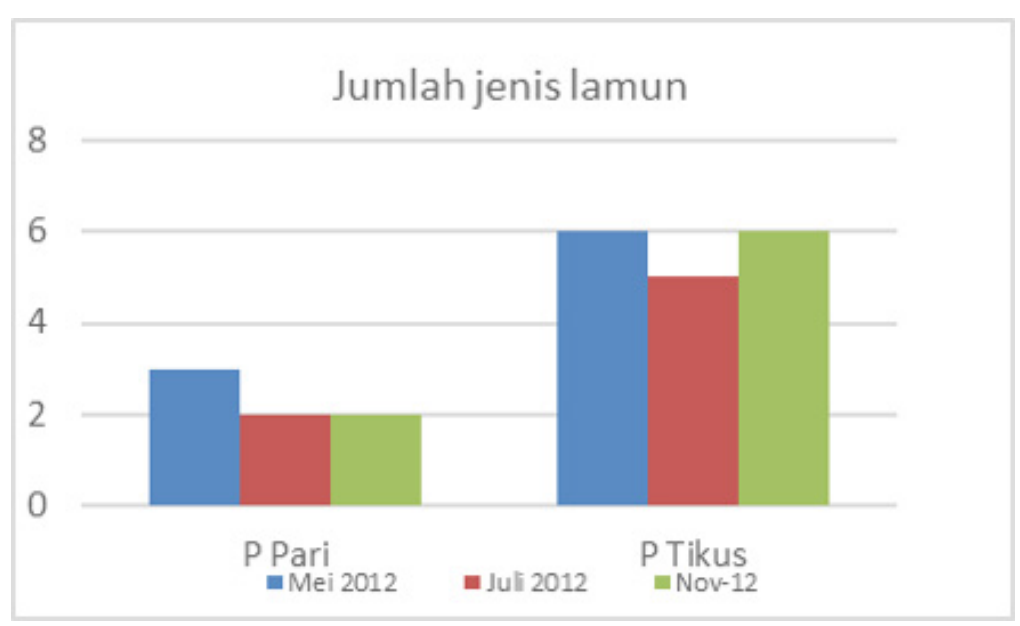

Gambar 3. Jumlah jenis lamun yang ditemukan selama penelitian.

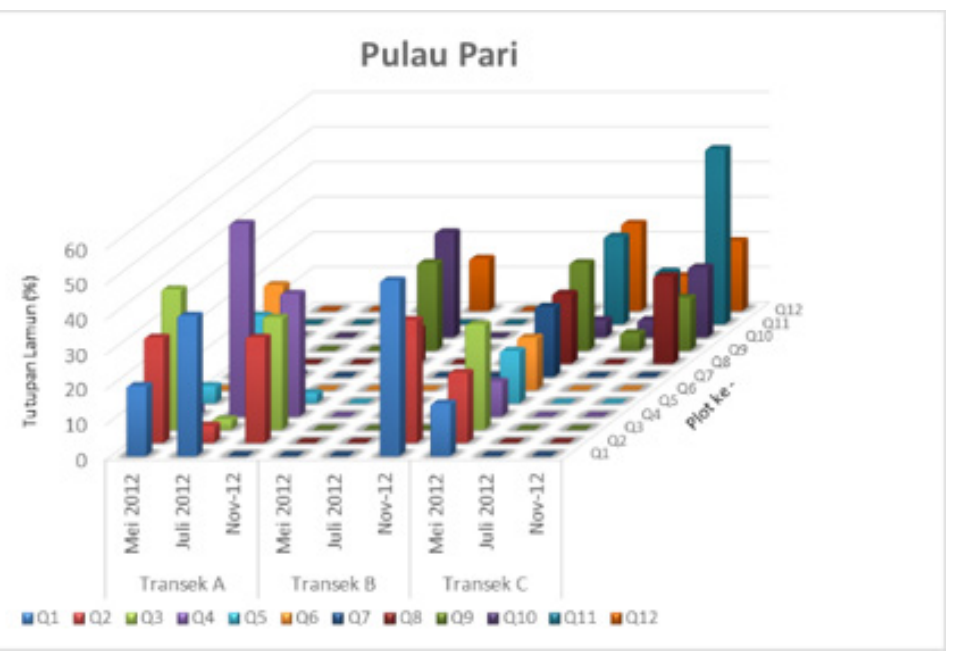

Gambar 4. Dinamika persentase total tutupan lamun di transek permanen Pulau Pari.

pembangunan resot di Pulau tengah tidak berpengaruh dengan mengindikasikan adanya peningkatan selama monitoring, dinamika ini dapat dilihat pada Gambar 6 .

Terlihat pada pemantauan di Pulau Tikus umumnya keberadaan lamun cukup padat dekat dengan daratan dan jumlah jenis yang lebih banyak (Transek A dan Transek B) daripada transek C. Terlihat pada transek C susunan lamun sudah tergantikan dengan keberadaan karang (Gambar 7).

\section{Lamun sebagai bioindikator lingkungan}

Rerata yang dilakukan pertransek dari hasil monitoring pulau Tikus dan Pulau Pari menunjukkan lebih tinggi di Pulau Tikus. Terlihat di pulau Tikus selama penelitian ada kecenderungan meningkat baik setiap transek (Gambar 8 atas) maupun per pulau (Gambar 8 bawah). Sehingga dapat dikatakan hipotesa awal penentuan lokasi permanen terpenuhi yaitu pulau Pari terindikasi mengalami tekanan akibat aktivitas daratan di dekatnya dan sekitarnya.
Keberadaan ekosistem lamun sebagai biondikator kesehatan lingkungan sudah dipakai di berbagai belahan dunia (Marba et al., 2013). Sampai saat ini peraturan yang ada di Indonesia terkait kesehatan lamun dan mengacu kepada lingkungan adalah KMNLH No 200 Tahun 2004. Penilaian yang dilakukan berdasarkan persentase tutupan total lamun dengan kriteria nilai persentase penutupan: $\geq 60 \%$ baik, dengan kondisi kaya atau sehat; $30-59,9 \%$ rusak dengan kondisi kurang kaya /kurang sehat dan $\leq 29,9 \%$ rusak dengan kondisi miskin.

Berdasarkan KMNLH No 200 Tahun 2004, maka kesehatan lamun selama penelitian untuk ke dua lokasi Pulau Pari dan Pulau Tikus semuanya dalam keadaan rusak dan kondisi miskin dengan nilai rerata lebih tinggi di Pulau Tikus (Tabel 1). Kecuali pada bulan November 2012 di Pulau Tikus rusak dengan kondisi kurang kaya/kurang sehat. 


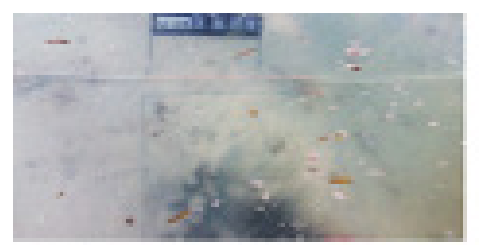

Q Pari Tramek A plat 1 (AD1) Mei2012

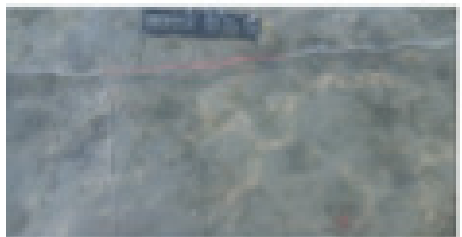

P Pari Trannek C plot 7 iCoO) Mei 2012

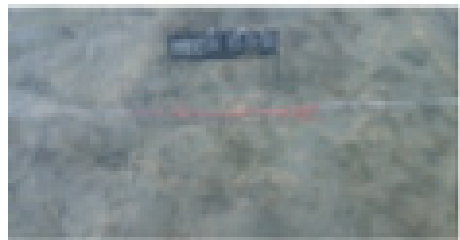

P Pari Transek C plot 12 (C12) Mei 2012

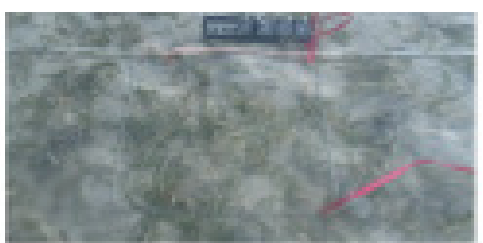

P Pari Transek A plot 1 (a01) Juli 2012

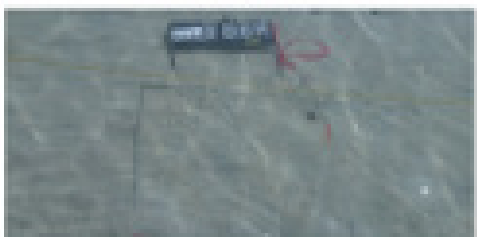

DPari Trmek C plot 7 iCD7\} MAi 2012

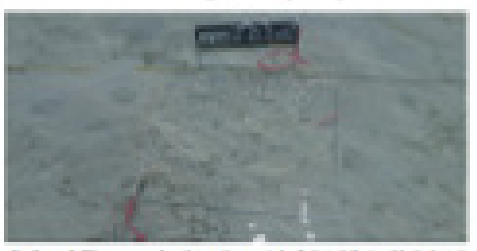

P Pari Transek C plot 12 [C12] Juli 2012

Gambar 5. Foto plot/kuadrat monitoring di Pulau Pari.

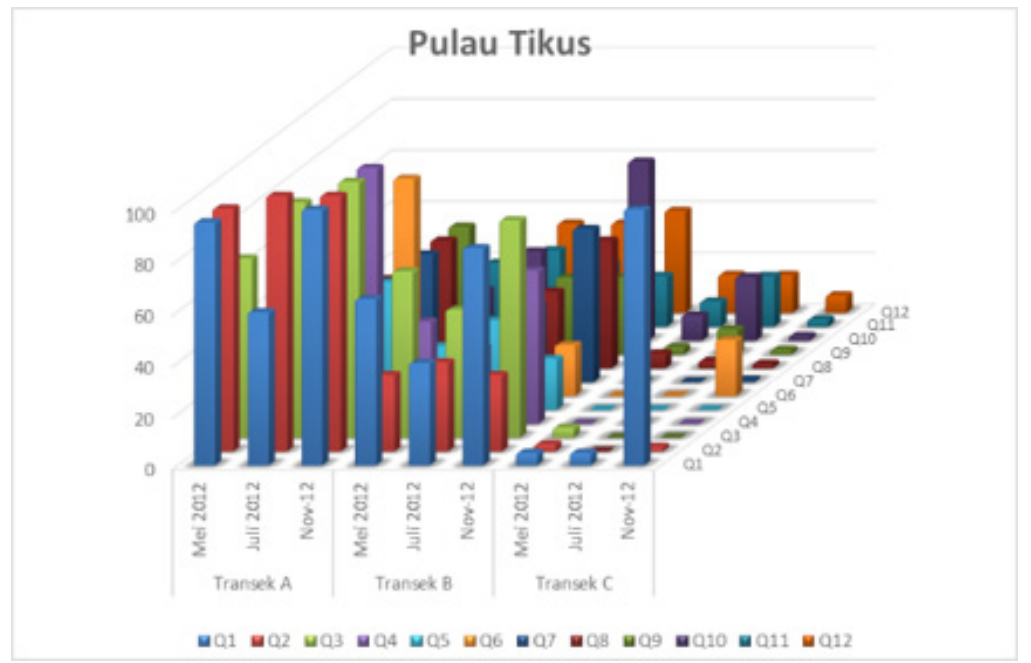

Gambar 6. Dinamika persentase total tutupan lamun di transek permanen Pulau Tikus.

Berdasarkan tabel 1 di atas secara keseluruhan kondisi ekosistem lamun dan kondisi lingkungan perairan mengindikasikan terjadinya degradasi. Hal ini akan berpengaruh pada layanan ekosistem lamun yang diberikan untuk ekosistem lainnya (terumbu karang dan mangrove) dan biota yang hidup di ekosistem tersebut seperti ikan.

\section{KESIMPULAN DAN SARAN}

Tujuh jenis lamun yang ditemukan di gugusan pulau Pari dengan dua family. Famili Hydrocharitaceae tiga jenis yaitu Enhalus acoroides (Ea), Thalassia hemprichii (Th), dan Halophila ovalis (Ho). Empat jenis dari famili Cymodoceaceae yaitu Cymodocea serrulata
(Cs), Cymodocea rotundata $(\mathrm{Cr})$, Halodule uninervis (Hu) dan Syringodium isoetifolium ( $\mathrm{Si}$ ). Lamun yang ditemukan di lokasi permanen pulau Pari ada tiga jenis yaitu Enhalus acoroides (Ea), Thalassia hemprichii (Th), dan Cymodocea rotundata $(\mathrm{Cr})$. Sedangkan di pulau Tikus ada enam jenis yaitu Enhalus acoroides (Ea), Thalassia hemprichii (Th), Halodule uninervis $(\mathrm{Hu})$, Syringodium isoetifolium $(\mathrm{Si})$, Cymodocea serrulata (Cs) dan Cymodocea rotundata (Cr). Berdasarkan penutupan total rata-rata lamun kondisi dan status ekosistem lamun di lokasi penelitian selama monitoring dalam kondisi rusak. Hal ini menunjukkan adanya degradasi lamun dengan tekanan lebih besar di Pulau Pari dibandingkan Pulau Tikus.. Pemantauan yang berkelanjutan di lokasi permanen terkait dengan 

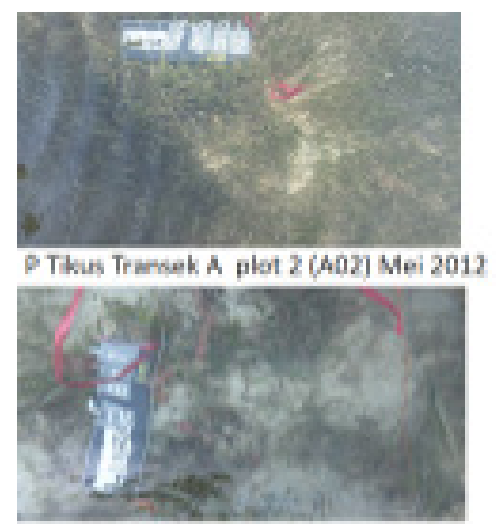

P Tkus Tramek B plot 13 [B14) Mei 2012

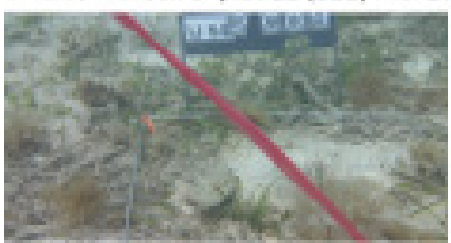

P Tikus Transek C plet 9 (C09) Mei 201 ?

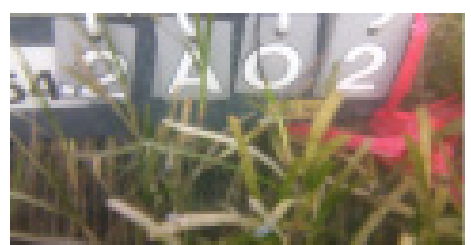

P Thus Transek A plot 2 (A02) Jul 2012
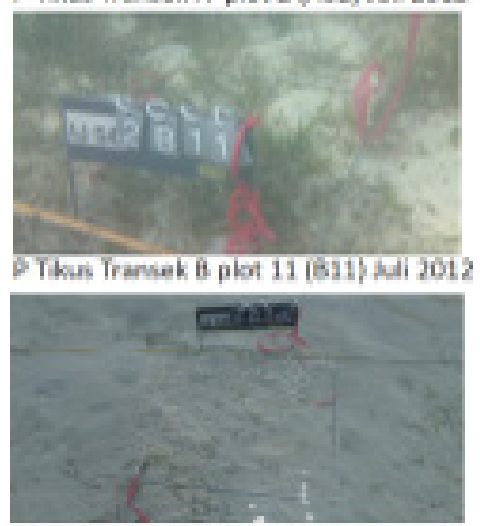

P Tikus Trancek C plot 9 [Cog| Juli 2012

Gambar 7. Foto plot/kuadrat monitoring di Pulau Tikus.

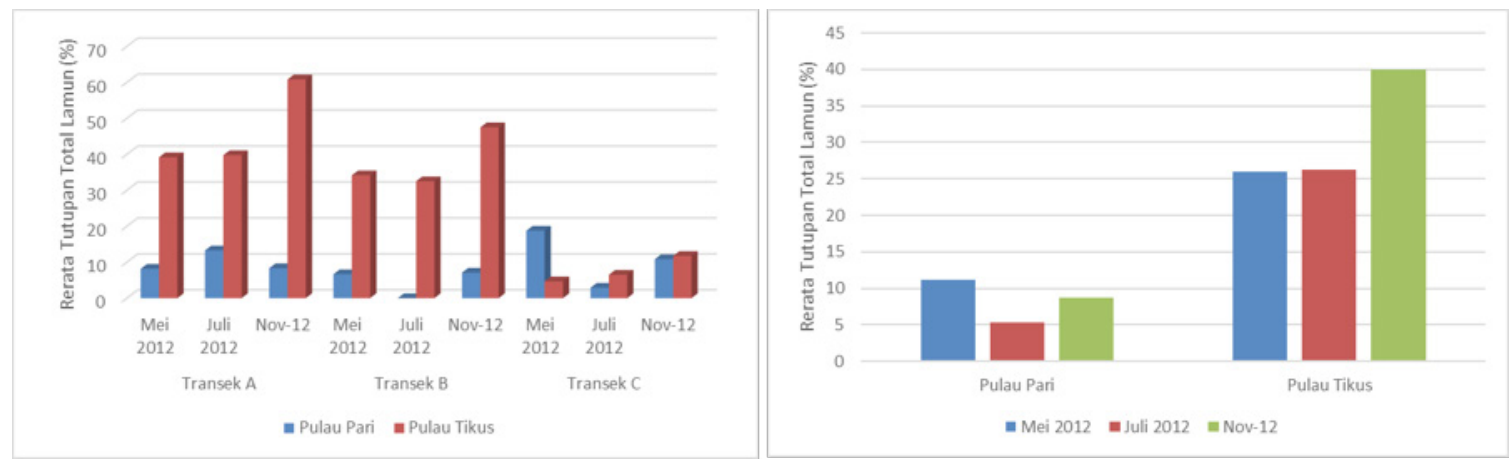

Gambar 8. Dinamika rerata persentase total tutupan lamun setiap transek permanen (atas) setiap pulau (bawah).

Tabel 1. Status kondisi padang lamun di Pulau Tikus dan Pulau Pari tahun 2012 berdasarkan KMNLH No 200 tahun 2004

\begin{tabular}{llll}
\hline & Penutupan (\%) & Kondisi \\
\hline PP Mei & 11 & Rusak & Miskin \\
PP Juli & 5 & Rusak & Miskin \\
PP Nov & 9 & Rusak & Miskin \\
PT Mei & 26 & Rusak & Miskin \\
PT Juli & 26 & Rusak & Miskin \\
PT Nov & 40 & Rusak & Kurang kaya/ \\
& & & kurang sehat \\
\hline Keterangan: PP= Pulau Pari PT = Pulau Tikus &
\end{tabular}

sifat ekologi lamun yang akan terdegradasi secara perlahan jika terjadi pencemaran bahan organik yang disebabkan pengayaan nutrien dari daratan maupun aktivitas fisik lainnya. Tingginya aktivitas wisatawan, perlu diperhatikan pengelolaan yang baik. Misalnya diperlukan pemahaman tentang ekowisata yang baik bagi wisatawan dan masyarakat lokal, salah satui contoh adalah dalam penanganan limbah/sampah domestik. Selain itu bias juga menerapkan aksi restorasi ekosistem lamun misalnya melalui transplantasi lamun yang melibatkan wisatawan dan masyarakat lokal. Adanya daerah perlindungan lain yang ditentukan secara lokal oleh masyarakat. Sehingga diharapkan pemanfatan ekosistem yang berkelanjutan dalam tujuan pembangunan berkelanjutan dapat dilakukan sehingga masyarakat tetap dapat layanan ekosistem 
dan peningkatan pendapatan.

\section{UCAPAN TERIMA KASIH}

Tulisan ini merupakan sebagian hasil kegiatan penelitian mandiri dalam menyelesaikan tugas akhir. Terimakasih diucapkan pada Pusat Penelitian dan Pengembangan Sumberdaya Laut dan Pesisir (P3SDLP), Badan Penelitian dan Pengembangan Kelautan dan Perikanan, Kementerian Kelautan dan Perikanan. Berdasarkan Peraturan Menteri Kelautan dan Perikanan Republik Indonesia Nomor 6/PERMEN-KP/2017 tentang Organisasi dan Tata Kerja Kementerian Kelautan dan Perikanan, institusi ini menjadi Pusat Riset Kelautan, Badan Riset dan Sumberdaya Manusia Kelautan dan Perikanan.

\section{DAFTAR PUSTAKA}

Costanza, R., R. d'Argue, R. de Groot, S. Farber, M. Grasso, B. Hannon, K. Limburg, S. Naeem, R. V. O’Neill, J. Paruelo, R. G. Raskin, P. Sutton \& M. van den Belt. (1997). The value of the world's ecosystem services and natural capital. Nature 387: 253-260.

KMNLH Keputusan Menteri Negara Lingkungan Hidup No. 200 tahun 2004. Tentang kriteria baku kerusakan dan pedoman penentuan status padang lamun. Jakarta

Kuo, J. (2007). New monoecious seagrass of Halophila sulawesii (Hydrocharitaceae) from Indonesia. Aquatic Botany, Vol. 87:171-175. doi:10.1016/j. aquabot.2007.04.006

Li, Lei \& Huang Xiaoping. (2012). Three tropical seagrasses as potential bio-indicators to trace metal in Xincun Bay, hainan Island, South China. Chinese Journal of Oceanology and Limnology, Vol 30(2):212-224. DOI: http:// dx.doi.org/10.1007/s00343-012-1092-0

Marba, N., Krause-Jensen, D., Alcoverro, T., Birk, S., Pedersen, A., Neto, J.M., Orfanidis, S., Garmendia, J.M., Muxika, I., Borja, A., Dencheva, K., \& Duarte, C.M. (2013). Diversity of European seagrass indicators: patterns within and across regions. Hydrobiologia, Vol. 704:265-278. DOI 10.1007/s10750-012-1403-7

McKenzie. Campbell, S.J., \& Roder, C.A (2003).
Seagrasswatch: Manual for mapping \& monitring seagrass resources by community (citizen) volunteers 2 sd edition. The state of Queensland, Department of Primary Industries, CRC Reef. Queensland. pp 104

Nagelkerken, I., van der Velde, G., Verberk, W.C.E.P., \& Dorenbosch, M. (2006). Segregation along multiple resource axes in a tropical seagrass fish community. Mar Ecol Prog Ser. Vol. 308: 79-89

Nagelkerken, I., Roberts, C.M., van der Velde, G., Dorenbosch, M., van Riel, M.C., \& de la Morinière, E.C. (2002). How important are mangroves and seagrass beds for coral-reef fish? The nursery hypothesis tested on an island scale. Mar Ecol Prog Ser. Vol. 244: 299-305

Phillips, R.C., \& E.G. Menéz. (1988). Seagrasses. smithsonian contributions to the marine sciences. smithsonian institution. Press, Washington d.c., 34:pp. 105.

Rappe, RA. (2010). Population and community level indicator in assessment of heavy metal contamination in seagrass ecosystem. Special section Ocean Pollution. Coastal marine science, 34(1):198 - 204.

River Science. (2013). Using seagrass to understand the condition of the estuary. Goverment of Western Australia, Departement of Water. $8 \mathrm{p}$

Rustam A., T. L. Kepel, M. A. Kusumaningtyas., R.N Afiati, A. Daulat, D.D Suryono, N. Sudirman, Y. P. Rahayu P. Mangindaan, A. Heriati \& A. Hutahaean. (2015). Ekosistem lamun sebagai bioindikator lingkungan di P. Lembeh, Bitung, Sulawesi Utara. J Biologi Indonesia. (11)2: 233 $-241$.

Short, F.T., R.G, Coles \& C. Pergent-Martini. 2001. Global seagrass distribution. Dalam: Short, FT \& R. Coles (eds.). Global Seagrass Research Methods. Elsevier Science B.V. Amsterdam. 5 30.

Short, F.T., Koch, E.W., Creed, J.C., Magalhaes, K.M., Gaeckle, J.L., \& Fernandez, E. (2006a). SeagrassNet monitoring across the Americas: case studies of seagrass decline. Marine Ecology. 277-289. Blackwell Publishing Ltd. ISSN 01739565 
Short, F.T., McKenzie, L.J., Coles, R.G., Vidler, K.P., \& Gaeckle, J.L. (2006). SeagrassNet: Manual for Scientific Monitoring of Seagrass Habitat. Worldwide Edition. 75 p. 
